\title{
Dietary restriction in the periconceptional period in normal-weight or obese ewes results in increased abundance of angiotensin-converting enzyme (ACE) and angiotensin type 1 receptor (AT1R) in the absence of changes in $A C E$ or $A T 1 R$ methylation in the adrenal of the offspring
}

\author{
Song Zhang ${ }^{1}$, Janna L Morrison ${ }^{1}$, Amreet Gill ${ }^{1}$, Leewen Rattanatray ${ }^{1,2}$, \\ Severence M MacLaughlin ${ }^{1}$, David Kleemann ${ }^{3}$, Simon K Walker ${ }^{3}$ and I Caroline McMillen ${ }^{1}$ \\ ${ }^{1}$ School of Pharmacy and Medical Sciences, Sansom Institute for Health Research, University of South Australia, \\ Adelaide, South Australia 5000, Australia, ${ }^{2}$ Discipline of Physiology, School of Molecular and Biomedical Science, \\ University of Adelaide, Adelaide, South Australia 5005, Australia and ${ }^{3}$ South Australian Research and \\ Development Institute, Turretfield Research Centre, Rosedale, South Australia 5350, Australia
}

Correspondence should be addressed to S Zhang; Email: song.zhang@unisa.edu.au

\begin{abstract}
Exposure to dietary restriction during the periconceptional period in either normal or obese ewes results in increased adrenal growth and a greater cortisol response to stress in the offspring, but the mechanisms that programme these changes are not fully understood. Activation of the angiotensin type 1 receptor (AT1R) has been demonstrated to stimulate adrenal growth and steroidogenesis. We have used an embryo transfer model in the sheep to investigate the effects of exposure to dietary restriction in normal or obese mothers from before and 1 week after conception on the methylation status, expression, abundance and localisation of key components of the renin-angiotensin system (RAS) in the adrenal of post-natal lambs. Maternal dietary restriction in normal or obese ewes during the periconceptional period resulted in an increase in angiotensin-converting enzyme (ACE) and AT1R abundance in the absence of changes in the methylation status or mRNA expression of $A C E$ and $A T 1 R$ in the adrenal of the offspring. Exposure to maternal obesity alone also resulted in an increase in adrenal AT1 R abundance. There was no effect of maternal dietary restriction or obesity on ACE2 and AT2R or on ERK, calcium/calmodulin-dependent kinase II abundance, and their phosphorylated forms in the lamb adrenal. Thus, weight loss around the time of conception, in both normal-weight and obese ewes, results in changes within the intra-adrenal RAS consistent with increased AT1R activation. These changes within the intra-adrenal RAS system may contribute to the greater adrenal stress response following exposure to signals of adversity in the periconceptional period.
\end{abstract}

Reproduction (2013) $\mathbf{1 4 6} 443-454$

\section{Introduction}

There is evidence from a range of experimental and clinical studies that exposure of the embryo, fetus or neonate to a range of environmental stressors such as poor nutrition, placental dysfunction, excess glucocorticoids or poor maternal care alters the development of the hypothalamo-pituitary-adrenal (HPA) axis and stress responsiveness of the offspring for life (Levitt et al. 1996, Phillips et al. 2000, Butler et al. 2002, Weaver et al. 2004, de Vries et al. 2007). Adversity in early life can result in long-term changes in the HPA axis as a consequence of epigenetic modifications of key regulatory genes in rodents, sheep and humans (Weaver et al. 2004, Oberlander et al. 2008, Murgatroyd et al. 2009, Stevens et al. 2010, Zhang et al. 2010,
Grace et al. 2011). It has previously been demonstrated in sheep that exposure to maternal undernutrition during the periconceptional period and early gestation results in altered fetal adrenal development from as early as 55 days of gestation (term $=150 \pm 3$ days of gestation; MacLaughlin et al. 2007), an earlier prepartum activation of the fetal HPA axis (Edwards \& McMillen 2002b, Bloomfield et al. 2004), an increased risk of premature delivery (Bloomfield et al. 2003) and increased plasma cortisol concentrations in the post-natal lamb (Gardner et al. 2006, Chadio et al. 2007). We have also recently reported that exposure to dietary restriction during the periconceptional period in either normal-weight or overweight ewes using the same animals in the current study results in increased adrenal growth, a greater 
cortisol response to stress and a decrease in the adrenal expression and methylation levels of the imprinted gene, insulin-like growth factor 2 (IGF2) in the offspring (Zhang et al. 2010). The increase in the cortisol stress response was not associated with an increase in plasma adrenocorticotrophin (ACTH) or an increase in the expression of steroidogenic enzymes within the adrenal, and we therefore proposed that the programming of the increased stress response may be a result of an increase in adrenocortical growth (Zhang et al. 2010). Interestingly, exposure to maternal obesity in the periconceptional period results in an increase in adrenal IGF1 mRNA expression in the absence of a change in adrenal mass in the post-natal lamb (Zhang et al. 2010). It is not clear, however, how exposure of the oocyte and/or early embryo to either maternal undernutrition or obesity results in the programming of altered adrenal growth, intra-adrenal IGF expression and cortisol output in later life.

In addition to the systemic renin-angiotensin system (RAS), there is also an intra-adrenal RAS (Bader \& Ganten 2008, Peters 2012). Renin acts to convert angiotensinogen into angiotensin I (Ang I), which is then converted to Ang II by angiotensin-converting enzyme (ACE). ACE2 is an ACE homologue that cleaves Ang I and Ang II into smaller Ang peptides. Ang 1-7 has vasodilatory and antiproliferative properties and antagonises the actions of Ang II (Roks et al. 1999, Lambert et al. 2008). It is well known that Ang II stimulates the growth of the zona glomerulosa (ZG) of the adrenal and aldosterone secretion; however, the role of Ang II in the zona fasciculata-reticularis (ZF-ZR) of the adrenal is less well established (Hoeflich \& Bielohuby 2009, Hattangady et al. 2012). It has been shown that Ang II stimulates growth, glucocorticoid secretion and steroidogenic capacity in cultured adrenal fasciculata-reticularis cells and adrenal growth in genetically hypertensive Lyon rats (Nussdorfer et al. 1981, Finn et al. 1988, Viard et al. 1990, Clyne et al. 1993, Lebrethon et al. 1994, McEwan et al. 1999, Aguilar et al. 2004, Romero et al. 2006).

Ang II acts on both type 1 (AT1R) and type 2 (AT2R) Ang receptors. A range of in vitro and in vivo experiments have shown that Ang II acts on AT1R to stimulate cellular proliferation and hypertrophy in the adrenal and to increase adrenal steroid secretion (Clyne et al. 1993, McEwan et al. 1999, Aguilar et al. 2004, Romero et al. 2006). AT1R activation results in the activation/phosphorylation of the MAPK pathways, including MEK-ERK1/2 and calcium/calmodulindependent kinases (Fern et al. 1995, Côté et al. 1998, Condon et al. 2002, Otis et al. 2005, Szekeres et al. 2009).

In rats, exposure to a maternal low-protein diet in pregnancy resulted in decreased methylation of the adrenal At1r and increased At1r mRNA expression and protein abundance and adrenal Ang responsiveness in offspring (Bogdarina et al. 2007). More recently, Bogdarina et al. (2010) reported that when rat dams fed a low-protein diet were treated with the $11 \beta$-hydroxylase inhibitor, metyrapone, which acts to decrease the adrenal output of maternal corticosterone, during the first 2 weeks of pregnancy, the changes in adrenal At1r methylation and mRNA expression in the offspring were reversed. In mice, a maternal low-protein diet during the second half of gestation also resulted in decreased Ace methylation and increased Ace mRNA expression in the fetal brain (Goyal et al. 2010). There have been no studies, however, that have investigated the effects of exposure to either maternal obesity or dietary restriction during the periconceptional period on the epigenetic state and mRNA expression of the key components of the intra-adrenal RAS in the offspring.

In this study, we have used a model in which 'donor' ewes were either normally nourished or overnourished prior to a period of dietary restriction, before transfer of the embryo at 6-7 days after conception to a ewe of normal weight. We hypothesised that maternal dietary restriction during the periconceptional period in either normal or obese ewes would result in the recruitment of epigenetic mechanisms, which would act to decrease the methylation of $A T 1 R$ and thereby result in AT1R activation of the downstream signalling pathways and an up-regulation of the intra-adrenal RAS in the offspring. We have therefore investigated the methylation status, expression and localisation of key components of the RAS in the ZG and ZF-ZR in the adrenal cortex of post-natal lambs conceived in either normal or obese ewes exposed to maternal undernutrition in the periconceptional period.

\section{Materials and methods}

\section{Animals and nutritional feeding regimen}

All procedures were approved by the University of Adelaide Animal Ethics Committee and the Institute for Medical and Veterinary Science Animals Ethics Committee. Briefly, South Australian Merino ewes were moved into an enclosed shed and housed in individual pens 2 weeks before the start of the feeding regimen. All ewes were weighed and body condition scores (BCSs) were assessed employing a 1.0-5.0 scale with 0.5 intervals by an experienced assessor (Russel et al. 1969, Greenwood et al. 2000). Using this scale, a BCS of 1 represents an extremely emaciated animal and a BCS of 5 represents a morbidly obese animal. During this 2-week period, ewes were acclimatised to a diet containing cereal hay, lucerne hay, barley, oats, almond shells, lupins, oat bran, lime and molasses (Johnsons \& Sons Pty Ltd., Kapunda, SA, Australia). The pellets provided $9.5 \mathrm{MJ} / \mathrm{kg}$ metabolisable energy and $120 \mathrm{~g} / \mathrm{kg}$ crude protein and contained $90.6 \%$ dry matter. All ewes received $100 \%$ of nutritional requirements as defined by the Agricultural and Food Research Council (Agricultural and Food Research Council 1993). 


\section{Donor ewes}

At the end of this acclimatisation period, donor ewes $(n=23)$ of normal body condition with a BCS of 3.0-3.5 were randomly assigned to one of four nutritional treatment groups, either control-control (CC), control-restricted (CR), high-high $(\mathrm{HH})$ or high-restricted (HR) (Rattanatray et al. 2010, Zhang et al. 2010).

i) CC ewes $(n=6)$ were a control group that were maintained at $100 \%$ metabolisable energy requirements (MER) for 5 months before and 1 week after conception;

ii) CR ewes $(n=6)$ were maintained at $100 \%$ MER for the first 4 months and then were placed on an energyrestricted diet of $70 \%$ MER for 1 month before and 1 week after conception;

iii) $\mathrm{HH}$ ewes $(n=6)$ were fed an ad libitum diet $(170-190 \%$ MER) for 5 months before and 1 week after conception; and

iv) HR ewes $(n=5)$ were fed an ad libitum diet (170-190\% MER) for 4 months and then were placed on an energyrestricted diet of $70 \%$ MER for 1 month before and 1 week after conception.

There was no significant difference in weights of nonpregnant donor ewes in the $\mathrm{CC}, \mathrm{CR}, \mathrm{HH}$ and $\mathrm{HR}$ treatment groups before the start of the nutritional regimen (Rattanatray et al. 2010, Zhang et al. 2010). Donor ewes were weighed and their BCS was assessed approximately every 2 weeks after commencing the feeding regimen until embryo transfer at 6-7 days after conception. At conception and at embryo transfer, donor ewes in the $\mathrm{HH}$ and $\mathrm{HR}$ groups were significantly heavier and fatter than ewes in the CC and CR groups (Rattanatray et al. 2010, Zhang et al. 2010).

\section{Superovulation, artificial insemination and embryo collection}

The reproductive cycle of all experimental ewes was synchronised and superovulation was induced as described previously (Kakar et al. 2005, Rattanatray et al. 2010). Fresh semen was collected from a ram of proven fertility as described previously (Kakar et al. 2005). Donor ewes were inseminated by laparoscopy with $\sim 2 \times 10^{7}$ spermatozoa being placed directly into lumen of each uterine horn $36 \mathrm{~h}$ after pessary withdrawal. Embryos were collected by mid-ventral laparotomy via flushing of uterine horns with saline (Baxter, Old Toongabbie, NSW, Australia) 6-7 days after artificial insemination. Embryos were then held at $38.5^{\circ} \mathrm{C}$ in HEPES-buffered synthetic oviduct fluid supplemented with BSA and amino acids at oviduct fluid concentrations.

\section{Recipient ewes}

Donor embryos of good quality were recovered and transferred to synchronised recipient ewes. These ewes were maintained on a control diet (100\% MER) throughout the period when donor ewes were exposed to different nutritional treatments. Each recipient ewe received only one embryo, which resulted in four treatment groups, i.e. CC, $n=13 ; \mathrm{CR}$, $n=16 ; \mathrm{HH}, n=17$ and $\mathrm{HR}, n=16$. These ewes were then fed a control diet for the remainder of the pregnancy, which provided $100 \%$ MER for the maintenance of a pregnant ewe bearing a singleton fetus (Agricultural and Food Research Council 1993).

There was no effect of nutritional treatment during the periconceptional period on either the birth weight or body weight of lambs at 4 months. Male lambs were significantly heavier at birth and at 4 months compared with female lambs independent of the nutritional treatment (Rattanatray et al. 2010, Zhang et al. 2010).

\section{Post-mortem and tissue collection}

At 4 months of age, lambs were killed with a lethal overdose $(\sim 30 \mathrm{mg} / \mathrm{kg})$ of sodium pentobarbitone delivered by i.v. injection (Virbac Pty Ltd., Peakhurst, NSW, Australia). Adrenals were collected and weighed. Relative adrenal weight was greater in the CR $(0.063 \pm 0.002 \mathrm{~g} / \mathrm{kg})$ and $\mathrm{HR}(0.060 \pm 0.003 \mathrm{~g} / \mathrm{kg})$ groups compared with the CC $(0.052 \pm 0.004 \mathrm{~g} / \mathrm{kg})$ and $\mathrm{HH}(0.053 \pm 0.002 \mathrm{~g} / \mathrm{kg})$ groups $(P<0.01)$ (Zhang et al. 2010). There was no effect of lamb sex on adrenal weights. Half of each right adrenal was fixed in $4 \%$ paraformaldehyde before embedding in paraffin wax and the remainder of the right adrenal and the left adrenal were frozen in liquid nitrogen and subsequently stored at $-80^{\circ} \mathrm{C}$.

\section{Methylation analysis}

DNA methylation within the promoter of $A C E$ and $A T 1 R$ was analysed by combined bisulphite restriction assay (COBRA; Xiong \& Laird 1997, Zhang et al. 2010). COBRA was performed using restriction endonucleases that cleave only those amplicons derived from methylated templates. Approximately $2 \mu \mathrm{g}$ DNA from individual adrenals (CC, $n=7 ; \mathrm{CR}, n=10$; $\mathrm{HH}, n=12$ and HR, $n=12$ ) were subjected to bisulphite conversion (Epitect, Qiagen). PCR was performed on $100 \mathrm{ng}$ bisulphite-converted DNA using primers and conditions that amplified methylated and unmethylated templates with no bias (Table 1). For ACE, the amplicon of a $179 \mathrm{bp}$ fragment derived from the promoter (GenBank accession no. DQ885942, - 500 to $-322 \mathrm{bp}$ relative to the transcription start site) was examined and digested with Rsal (New England Biolabs, Ipswich, MA, USA) for $2 \mathrm{~h}$ at $37^{\circ} \mathrm{C}$. For $A T 1 R$, the amplicon of a $168 \mathrm{bp}$ fragment derived from the promoter (http://genome. ucsc.edu/, -175 to $-8 \mathrm{bp}$ relative to the transcription start site) was examined and digested with BstBI or Tail (New England Biolabs). The intensity of uncut and cut fragments was

Table 1 Methylation primers for $A C E$ and $A T 1 R$ loci.

\begin{tabular}{llc}
\hline & Primer sequences $\left(5^{\prime}-3^{\prime}\right)$ & $\begin{array}{c}\text { Amplicon } \\
\text { size }(\mathrm{bp})\end{array}$ \\
\hline ACE & $\begin{array}{l}\text { Forward: GGATAGTTTTTTTATTTTGTTATTT } \\
\text { Reverse: CTATAAAACTAAAACACCCAA- }\end{array}$ & 179 \\
& CAATTTACT & \\
AT1R & $\begin{array}{l}\text { Forward: GATGGTTGTGGTATTATTTTTTTT } \\
\text { Reverse: TCTAAAACAACTCCAAATTTATAAC }\end{array}$ & 168 \\
& & \\
\hline
\end{tabular}

Reproduction (2013) $146443-454$ 
quantified using an Experion Automated Electrophoresis System (Bio-Rad Laboratories). Percentage of methylation was estimated by measuring the ratio of cut to the sum of cut and uncut PCR product.

\section{Quantification of mRNA expression using quantitative real-time $R T$-PCR}

Total RNA was extracted from adrenal samples (CC, $n=7 ; \mathrm{CR}$, $n=10 ; \mathrm{HH}, n=12$ and HR, $n=12$ ) using the TRIzol Reagent (Invitrogen by Life Technologies) and purified using the RNeasy Mini Kit (Qiagen) (Zhang et al. 2010). cDNA was synthesised by RT using Superscript III (Invitrogen by Life Technologies). Negative controls containing no RNA or superscript III were used to test for DNA contamination.

The relative expression of mRNA transcripts of angiotensinogen, renin, $A C E, A C E 2, A T 1 R, A T 2 R$ and $11 \beta$ hydroxylase $(C Y P 11 B)$ in the adrenal was measured by quantitative realtime PCR using the ViiA 7 Real-Time PCR System (Applied Biosystems by Life Technologies). Each amplicon was sequenced to ensure the authenticity of the DNA product and melt curve analysis performed to demonstrate amplicon homogeneity. A PCR consisted of $3 \mu$ l Fast SYBR Green Master Mix (Applied Biosystems by Life Technologies), $0.6 \mu \mathrm{l}$ each of forward and reverse primers (GeneWorks, Adelaide, SA, Australia), $0.8 \mu \mathrm{l}$ molecular-grade $\mathrm{H}_{2} \mathrm{O}$ and $1 \mu \mathrm{l}$ cDNA (50 ng/ $\mu$ l) (Table 2; Dodic et al. 2002, Passmore et al. 2009). Three replicates of cDNA were performed for each gene, and controls with no cDNA were included on each plate. Amplification efficiencies were determined from the slope of a plot of $C$ t (defined as the threshold cycle with the lowest significant increase in fluorescence) against the log of a series of diluted cDNA concentrations (ranging from 1 to $100 \mathrm{ng} / \mu \mathrm{l}$ ). The abundance of each transcript relative to the abundance of the reference genes, peptidylprolyl isomerase A (PPIA) and glyceraldehyde 3-phosphate dehydrogenase $(G A P D H)$, was calculated using the free Q-Gene Analysis Software (Muller et al. 2002) and the data were reported as relative mRNA expression of the target gene to PPIA.

\section{Localisation and quantification of protein abundance by immunohistochemistry}

Adrenal sections $(7 \mu \mathrm{m})$ from lambs (CC, $n=5 ; \mathrm{CR}, n=6$; $\mathrm{HH}, n=6$ and $\mathrm{HR}, n=7$ ) were prepared and mounted on pre-treated slides (Superfrost Plus; Thermo Fisher Scientific, Scoresby, VIC, Australia) to localise ACE, ACE2, AT1R and AT2R using immunohistochemistry as described previously (Ross et al. 2007). In brief, the ACE, ACE2, AT1R and AT2R proteins were each visualised using a Zymed histostain-plus kit (Invitrogen by Life Technologies), which uses a broad-spectrum biotinylated secondary antibody that detects mouse, rabbit, guinea pig and rat primary antibodies, and a streptavidinHRP conjugate. The ACE, AT1R and AT2R primary antibodies were raised in rabbits and used at a dilution of 1:200 (Santa Cruz Biotechnology). The ACE2 primary antibody was raised in goats against human ACE2 and used at a dilution of 1:200 (Santa Cruz Biotechnology). For ACE2, instead of using the biotinylated secondary antibody and the HRP-conjugated streptavidin in the kit, the slides were incubated with 1:200 donkey anti-goat secondary antibody and HRP conjugate (Merck Millipore, Billerica, MA, USA). Matched samples without the use of the primary antibody were used as negative controls. A 3,3' diaminobenzidine substrate (Thermo Fisher Scientific) was then used as the chromogen to identify positive staining and the sections were lightly counterstained (Mayer's haematoxylin; Sigma-Aldrich). Slides were then dehydrated, mounted and coverslipped. The photomicrographic images were captured from an Olympus VANOX-AHT microscope (Olympus Optical Co., Ltd., Tokyo, Japan) using a Colorview I camera with AnalySIS image analysis software (Soft Imaging Systems, Gulfview Heights, SA, Australia).

All tissue sections from each treatment group were processed concurrently to allow for direct comparison between treatments. A semiquantitative analysis was used to assess the immunostaining intensity of ACE, ACE2, AT1R and AT2R in the ZG and ZF-ZR in the adrenal cortex. Two observers who were blinded to the treatment group for each slide used $a$ semiquantitative scoring system for the analysis ( $\times 20$ magnification). The intensity of staining was ranked by use of a

Table 2 Real-time PCR primer sequences and final primer concentrations for target and reference genes.

\begin{tabular}{|c|c|c|c|}
\hline Gene names & Primer sequences $\left(5^{\prime}-3^{\prime}\right)$ & Primer conc. $(\mu \mathrm{M})$ & GenBank accession no. \\
\hline \multirow[t]{2}{*}{ Angiotensinogen } & Forward: СТСТСССАСGСТСАСТАGАСТTG & 300 & NM_001114082.1 (Dodic et al. 2002) \\
\hline & Reverse: ATGCATGAACCTGTTGATCTTCTC & 300 & \\
\hline \multirow[t]{2}{*}{$A C E$} & Forward: AATTGССТTССТGСССТTTGGСТA & 200 & AJ920033.1 \\
\hline & Reverse: CCAGCGTCAAAGTGGGTTTCGTTT & 200 & \\
\hline \multirow[t]{2}{*}{ ACE2 } & Forward: AGAACCAGTCCTGGGATGCAGAAA & 450 & NM_001024502.2 \\
\hline & Reverse: AGTCAGCATGGAGTTGTCCCAGAA & 450 & \\
\hline \multirow[t]{2}{*}{$A T 1 R$} & Forward: GGGCTGTCTACACTGСTATGGAA & 300 & AF254119.1 (Dodic et al. 2002) \\
\hline & Reverse: CCGGAAGCGATCTTACATAGGTA & 300 & \\
\hline \multirow[t]{2}{*}{$A T 2 R$} & Forward: TGGCTTGTCTGTCCTCATTG & 450 & S81979.1 (Dodic et al. 2002) \\
\hline & Reverse: GCTGACCACTGGGCATACTT & 450 & \\
\hline \multirow[t]{2}{*}{ CYP11B } & Forward: AGGGAGACACATGGTGTTCGTGAT & 450 & U78477.1 \\
\hline & Reverse: GTTGAGCAAGAACACGCCACACTT & 450 & \\
\hline \multirow[t]{2}{*}{ PP1A } & Forward: TCATTTGCACTGCCAAGACTG & 900 & AY251270 (Passmore et al. 2009) \\
\hline & Reverse: TCATGCССТСТTTCАСТTTGC & 900 & \\
\hline \multirow[t]{2}{*}{$G A P D H$} & Forward: CСТGGAGAAACСТGCCAAGT & 900 & DQ152956.1 (Passmore et al. 2009) \\
\hline & Reverse: GCCAAATTCATTGTCGTACCA & 900 & \\
\hline
\end{tabular}


conventional five-point scoring system ( 0 , no staining; 1 , weak staining; 2, moderate staining; 3 , strong staining and 4, extremely strong staining; Belaud-Rotureau et al. 2002, Gross et al. 2007). A high concordance (>90\% exact agreement) was found between the scoring of the two assessors.

\section{Quantification of protein abundance by western blotting}

The protein abundance of AT1R, AT2R, ERK, p-ERK (Thr202/Tyr204), CAMKII and p-CAMKII (Thr286) was determined using western blotting as described in detail elsewhere (Forhead et al. 2008). Briefly, adrenal cortical samples (50 mg; CC, $n=6 ; \mathrm{CR}, n=6 ; \mathrm{HH}, n=6$ and $\mathrm{HR}, n=6)$ were sonicated in extraction buffer $(50 \mathrm{mmol} / \mathrm{l}$ Tris $(\mathrm{pH}), 150 \mathrm{mmol} / \mathrm{l}$ sodium chloride, $1 \% \mathrm{HP}-40,1 \mathrm{mmol} / \mathrm{l}$ sodium pyrophosphate, $10 \mathrm{mmol} / \mathrm{I}$ EDTA and a protease inhibitor cocktail) and centrifuged at $14300 \mathrm{~g}$ at $4{ }^{\circ} \mathrm{C}$ for $14 \mathrm{~min}$ to remove lipid and insoluble material. Protein content of extracts was determined using a Micro BCA protein assay kit (Pierce, Thermo Fisher Scientific, Inc., Rockford, IL, USA) with BSA to generate a standard curve. Equal amounts of protein $(20 \mu \mathrm{g})$ were subjected to SDS-PAGE. The proteins were transferred to PVDF membrane (Merck Millipore), blocked and then incubated with primary antisera raised against AT1R, AT2R and p-CAMKII from Santa Cruz Biotechnology and ERK, p-ERK and CAMKII from Cell Signalling Technology (Danvers, MA, USA) (Forhead et al. 2008). Membranes were washed and bound antibody detected using HRP-conjugated secondary antibodies and ECL reagents according to the manufacturer's instructions (Thermo Fisher Scientific). AlphaEaseFC Software (Alpha Innotech Corporation, San Leandro, CA, USA) was used to quantify the density of specific bands. To monitor the linearity of the density measurements, 10 and $20 \mu \mathrm{g}$ of the same protein sample were loaded onto each gel to confirm that the chemiluminescent signal changed in a linear manner for all experiments. Prior to western blotting analysis, samples (20 $\mu$ g protein) were subjected to SDS-PAGE and gels stained with Coomassie Brilliant Blue (Thermo Fisher Scientific) and there were no differences in abundance of the major proteins present in samples between the different experimental groups.

\section{Statistical analysis}

All data are presented as mean \pm S.E.M. Data were analysed using IBM Statistical Package for Social Scientists Statistics, Statistical Software for repeated measures (Stata Corp., College Station, TX, USA). The effects of periconceptional nutrition and sex on the levels of DNA methylation, mRNA expression and protein abundance in the adrenal of lambs at 4 months of age were determined using a two-way ANOVA (with periconceptional nutrition and lamb sex as the major factors) with donor ewe number nested within nutritional treatment groups to identify lambs arising from the same donor. When there was an interaction between the effects of periconceptional nutrition and sex, the effect of periconceptional nutrition was determined separately in males and females. The Duncan's post hoc test was sodium orthovanadate, $30 \mathrm{mmol} / \mathrm{l}$ sodium fluoride, $10 \mathrm{mmol} / \mathrm{l}$ version 19 (SPSS, Inc.) and STATA11: Data analysis and

www.reproduction-online.org

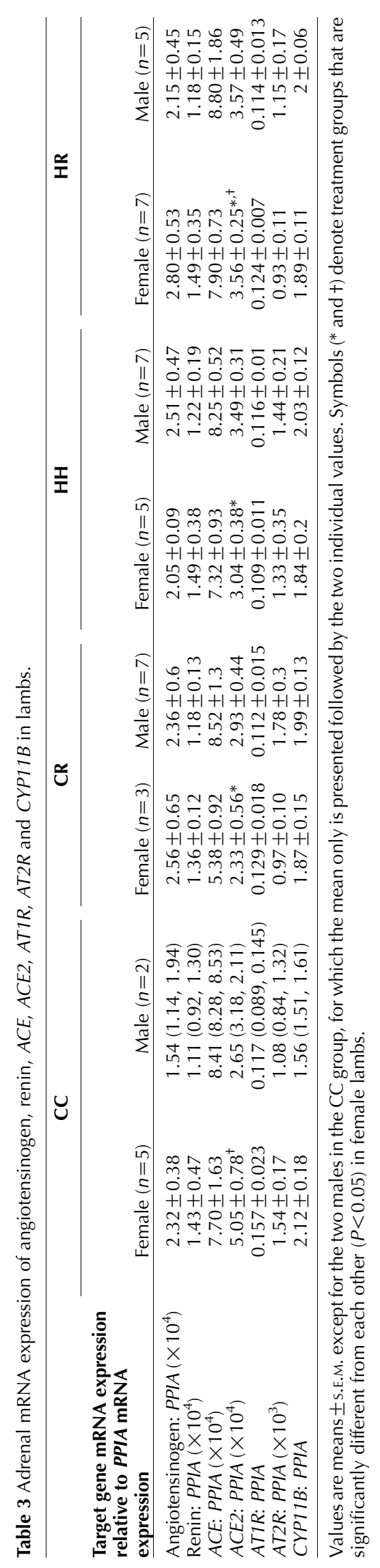

Reproduction (2013) $146443-454$ 
used to determine significant differences between groups and a probability level of $5 \%(P<0.05)$ was taken to be significant.

\section{Results \\ Impact of periconceptional nutrition on adrenal ACE and AT1R DNA methylation}

There was no effect of nutritional treatment, sex of the lamb or interaction between treatment and sex on $A C E$ methylation levels in the post-natal adrenal (CC, $5.1 \pm 2.0 \%$; CR, $6.5 \pm 1.4 \% ; \mathrm{HH}, 3.8 \pm 0.8 \%$ and $\mathrm{HR}$, $6.8 \pm 1.4 \%$ ). There was no methylation present on the two CpG sites analysed for the $A T 1 R$ gene promoter in the lamb adrenal in any treatment group.

\section{Impact of periconceptional nutrition on adrenal angiotensinogen, renin, ACE, ACE2, AT1R, AT2R and CYP11B TRNA expression}

There was no difference in adrenal mRNA expression of angiotensinogen, renin, $A C E, A T 1 R$ and $A T 2 R$ and $C Y P 11 B$ between the $C C, C R, H H$ and $H R$ groups or between male and female lambs (Table 3). There was a significant interaction between the effects of nutritional treatment and sex of the lamb on adrenal ACE2 mRNA expression $(P<0.05)$. In female lambs, adrenal ACE2 mRNA expression was significantly lower $(P<0.05)$ in the $\mathrm{CR}$ and $\mathrm{HH}$ lambs compared with the CC lambs (Table 3).

\section{Impact of periconceptional nutrition on adrenal ACE, $A C E 2, A T 1 R$ and $A T 2 R$ protein abundance}

The abundance of AT1R protein in the adrenal as determined by western blotting was significantly higher in the $\mathrm{CR}, \mathrm{HH}$ and $\mathrm{HR}$ groups compared with the CC group $(P<0.05$; Fig. $1 C)$. Strong AT1R immunostaining was predominantly present in the ZF-ZR and to a lesser extent in the ZG (Fig. 2E and F). The intensity of AT1R immunostaining was significantly higher in both the ZG and $Z F-Z R$ in the adrenals of the $C R$ and $H R$ groups compared with the $C C$ group $(P<0.05$; Fig. $1 \mathrm{~A}$ and $\mathrm{B})$.

$A C E$ immunostaining was present throughout the $Z G$ and ZF-ZR (Fig. 2A and B) and the intensity of ACE immunostaining was significantly higher in these zones in lambs in the CR and HR groups compared with the CC group $(P<0.05$; Fig. $3 \mathrm{~A}$ and $\mathrm{B})$. While ACE2 immunostaining was also present in the ZG and ZF-ZR, there was no difference in the staining intensity of adrenal ACE2 between nutritional treatment groups (Figs 2 C and D, 3 C and D).

There was no effect of maternal nutritional treatment on the abundance of AT2R protein (Figs $2 \mathrm{G}$ and $\mathrm{H}, 4$ ) and there was also no effect of lamb sex or an interaction between nutritional treatment and sex on the abundance of adrenal ACE, ACE2, AT1R and AT2R proteins as determined by either western blotting or immunostaining in the adrenal cortex of the post-natal lamb.
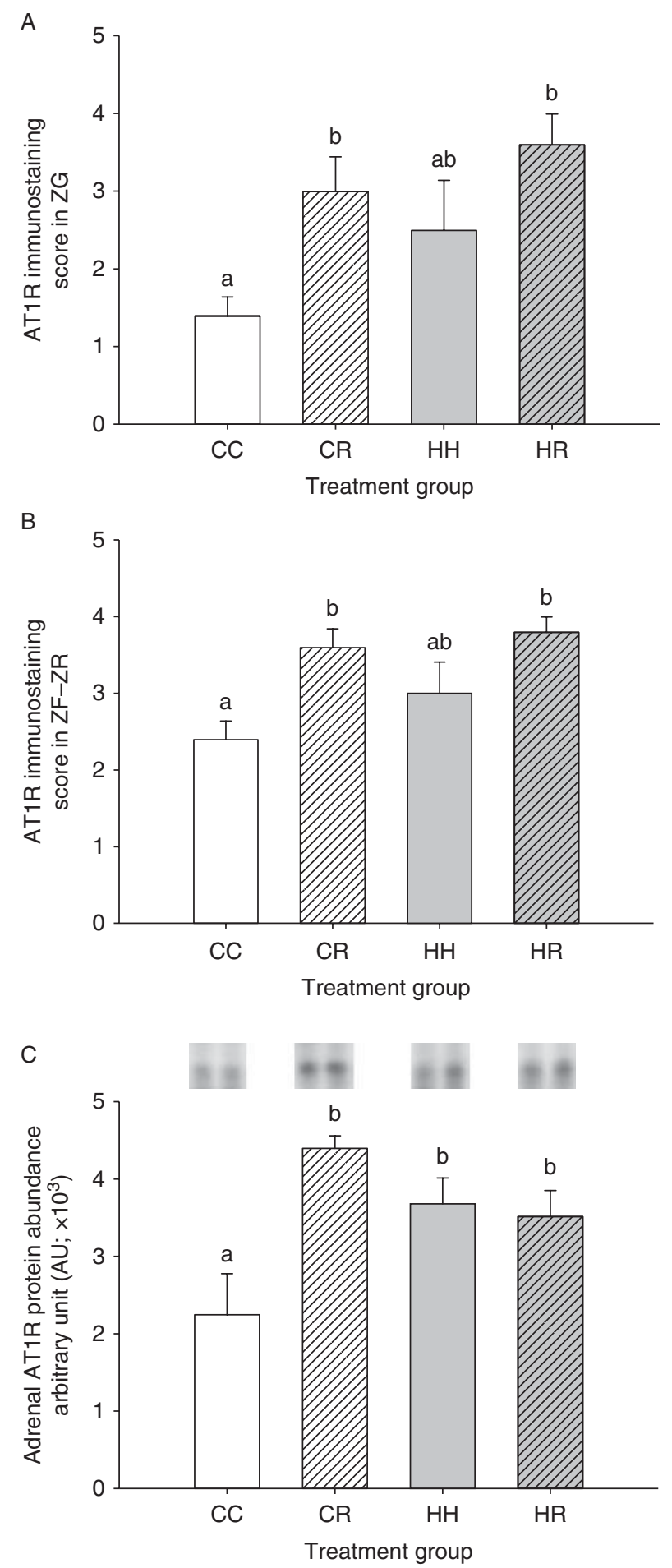

Figure 1 Intensity of AT1R immunostaining in the (A) ZG and (B) ZF-ZR of the adrenal cortex of the CC, CR, HH and HR lambs (CC, $n=5 ; \mathrm{CR}, n=6$; $\mathrm{HH}, n=6$ and HR, $n=7$ ) at 4 months of age. (C) Abundance of AT1R protein as determined by western blotting in the adrenal cortex of the $\mathrm{CC}$, $\mathrm{CR}, \mathrm{HH}$ and $\mathrm{HR}$ lambs (CC, $n=6 ; \mathrm{CR}, n=6 ; \mathrm{HH}, n=6$ and $\mathrm{HR}, n=6$ ). Representative western blots from two animals in each group for AT1R are presented. Different superscripts ( $a$ and $b$ ) denote mean values that are significantly different from each other $(P<0.05)$. 

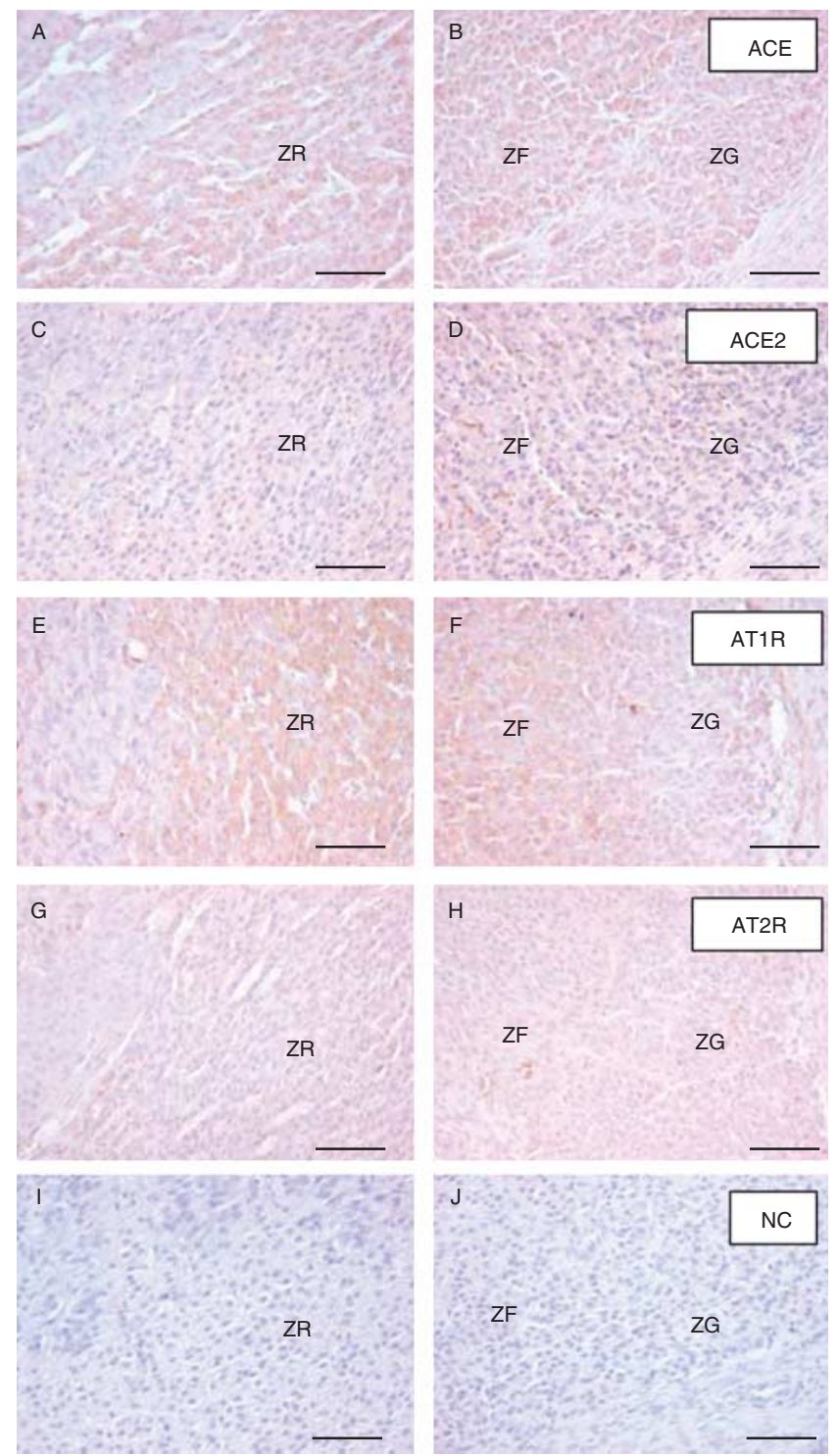

Figure 2 Representative sections showing the immuohistochemical localisation of ACE (A and B), ACE2 (C and D), AT1R (E and F) and AT2R $(G$ and $H)$ in adrenals from the lambs at 4 months of age. In the ZF-ZR, the immunostaining score was 4 for ACE and AT1R for the representative samples from the HR group, 3 for ACE2 for the sample from the CR adrenal and 3 for AT2R for the sample from the CC adrenal. Images (I and J) show the representative negative control (NC) in adrenal sections. The left-hand panel (A, C, E and G) shows the immunostaining in the $Z R$ while the right-hand panel (B, D, F and $H$ ) shows the immunostaining in the ZF and ZG. The brown colour represents specific staining of the target protein and the blue colour represents the haematoxylin counterstain. Bar $=50 \mu \mathrm{m}$.

\section{Impact of periconceptional nutrition on the protein abundance of adrenal AT1R downstream signalling molecules (ERK, p-ERK, CAMKII and p-CAMKII)}

There was no effect of nutritional treatment, sex of the lamb or interaction between the effects of treatment and sex on the protein abundance of the AT1R downstream signalling molecules including ERK, Thr202/Tyr204 phospho-ERK, CAMKII or Thr 286 phospho-CAMKII in the adrenals of the post-natal lambs (Fig. 5).

\section{Discussion}

The lack of changes in adrenal angiotensinogen or renin mRNA expression between the treatment groups suggests that maternal dietary restriction during the periconceptional period might have negligible impact on the upstream components of the intra-adrenal RAS, at least at the transcriptional level. We have demonstrated that dietary restriction in normal and obese ewes during the periconceptional period (CR and $\mathrm{HR}$ groups) resulted in an activation of the downstream components of the intra-adrenal RAS through an increase in the abundance of AT1R and ACE in the adrenal cortex of their offspring at 4 months of age. The intensity of ACE and AT1R, but not ACE2 or AT2R, immunostaining was higher in all zones of the adrenal cortex in the CR and HR lambs. These findings suggest that the impact of maternal dietary restriction on adrenal ACE and AT1R abundance is related to either a nutritional or hormonal signal of maternal weight loss in the ewe around the time of conception, rather than the body weight of the ewe in the periconceptional period. There was no effect, however, of maternal dietary restriction in either normal-weight or obese ewes on the DNA methylation levels within the $A C E$ and $A T 1 R$ promoter or on $A C E$ and $A T 1 R$ mRNA levels in the adrenals of the offspring. These findings suggest that the impact of maternal dietary restriction during the periconceptional period on adrenal ACE and AT1R abundance is not a consequence of epigenetic changes in the methylation status or the regulation of $A C E$ and $A T 1 R$ transcription and may rather be a consequence of a change in the regulation of the post-translational clearance of these proteins in the post-natal adrenal. One alternative explanation is that dietary restriction in the periconceptional period may result in the altered expression of microRNAs, small $\sim 22$ nucleotide-long non-coding RNAs, which play important roles as key post-transcriptional regulators of gene expression (Bushati \& Cohen 2007, Bartel 2009). Interestingly, it has been reported that miR-155 expression is reduced in hypertensive patients with a specific polymorphic genotype at the $3^{\prime}$ UTR of the AT1R gene and this is associated with higher AT1R protein abundance, despite similar AT1R mRNA expression (Ceolotto et al. 2011). We also found that there was a decrease in ACE2 mRNA, but not in the abundance of ACE2 in the adrenals of female lambs within the CR group, which could potentially contribute to increased Ang II activation in adrenals in these lambs.

A previous study in the sheep has shown that maternal nutrient restriction during early to mid gestation (28-77 days gestation) also resulted in an increase in $A T 1 R$ mRNA expression; however, changes in AT1R 

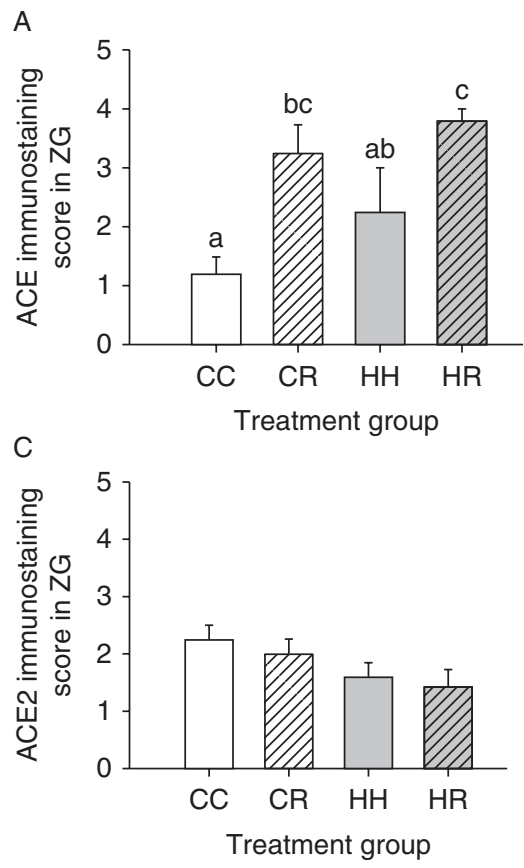


Figure 3 Intensity of ACE and ACE2 immunostaining in the ZG ((A) ACE and (C) ACE2) and ZF-ZR ((B) ACE and (D) ACE2) of the adrenal cortex of the CC, CR, $\mathrm{HH}$ and HR lambs (CC, $n=5 ; \mathrm{CR}, n=6 ; \mathrm{HH}, n=6$ and HR, $n=7)$ at 4 months of age. Different superscripts $(\mathrm{a}, \mathrm{b}$ and $\mathrm{c})$ denote mean values that are significantly different from each other $(P<0.05)$. protein abundance were not examined in this study (Whorwood et al. 2001). In the rat, exposure to global undernutrition throughout pregnancy did not alter adrenal Ace mRNA expression in the offspring (Rivière et al. 2005) whereas exposure to a maternal low-protein diet resulted in decreased methylation of adrenal Agtr1a and increased Agtr1a mRNA expression and protein abundance as well as adrenal Ang responsiveness in rat offspring (Bogdarina et al. 2007). It therefore appears that exposure to maternal undernutrition at different periods in early, mid and later gestation results in an increase in AT1R expression and/or abundance through the recruitment of a number of different regulatory pathways.

The up-regulation of the adrenal ACE and AT1R in the ZG and the ZF-ZR in the CR and HR lambs suggests that the activation of the intra-adrenal RAS in these lambs may play multiple roles in the regulation of adrenal growth and steroid secretion. We previously reported that exposure to dietary restriction during the periconceptional period in either normal or obese ewes results in increased adrenal growth and a greater cortisol response to stress in the offspring (Zhang et al. 2010). The increase in the cortisol stress response was not associated with an increase in plasma ACTH concentration or an increase in the expression of steroidogenic enzymes within the adrenal and we therefore proposed that the increased stress response was a consequence of the increase in adrenal mass (Zhang et al. 2010). Ang II has been shown to stimulate adrenal growth in the ZG and the ZF-ZR regions of the adrenal cortex (Nussdorfer et al. 1981, Finn et al. 1988, Viard et al. 1990, Clyne et al. 1993, Lebrethon et al. 1994, Romero et al. 2006, Hoeflich \& Bielohuby 2009, Hattangady et al. 2012). In genetically hypertensive Lyon rats, a 4-week infusion of Ang II resulted in an enlargement in both the ZG and the $Z F-Z R$ regions of the adrenal gland and an increase in plasma aldosterone and corticosterone concentrations, and the increase in ZF-ZR volume accounted for $63 \%$ of the adrenal hypertrophy (Aguilar et al. 2004).

It has been demonstrated that the activation of AT1R and its downstream signalling molecules, mainly ERK and/or CAMKII, mediate most of the biological functions of Ang II (Clyne et al. 1993, Fern et al. 1995, Côté et al. 1998, McEwan et al. 1999, Aguilar et al. 2004, Otis et al. 2005, Romero et al. 2006, Szekeres et al. 2009). In this study, while there was an increase in the abundance of AT1R, there was no difference in the protein abundance of ERK, CAMKII and their phosphorylated forms in the adrenal of the CR and HR lambs. It is possible that other downstream signalling pathways including c-Jun $\mathrm{N}$-terminal kinases (JNKs) or JAK/STAT may play a role in an AT1R stimulation of adrenal growth. It has been shown that Ang II acts on AT1R to stimulate the JAK/STAT pathway in vascular smooth muscle cells (Marrero et al. 1995) and JNKs mediate the proliferative effect of Ang II in cultured human kidney mesangial cells (Zhang et al. 2005); however, there are few studies on the roles of these signalling pathways in the adrenal.

One interesting finding in the current study was an increase in AT1R, but not ACE abundance in the adrenals of lambs exposed to maternal obesity in the periconceptional period. We have previously shown that there was an increase in adrenal IGF1 expression, which was not associated with an increase in adrenal growth in these lambs. While the increase in AT1R abundance suggests that there may be an impact of exposure to maternal obesity in the periconceptional period on the intraadrenal RAS, it appears that maternal dietary restriction 
A

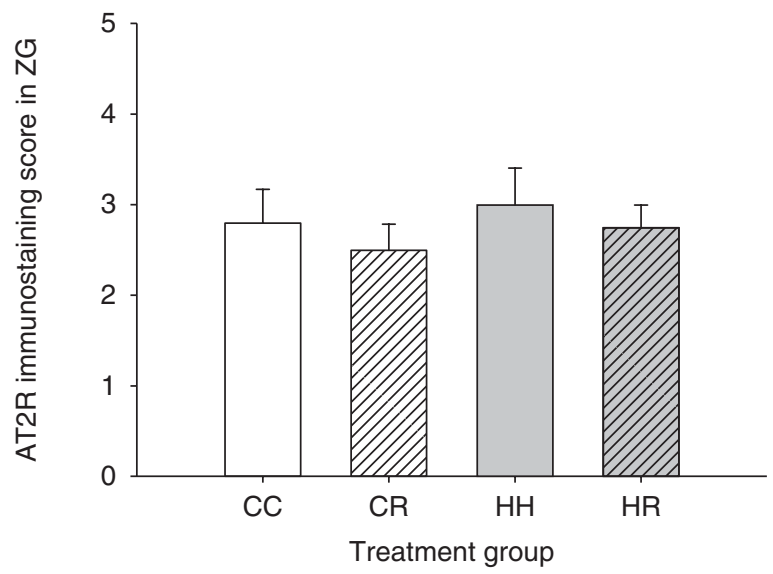

B

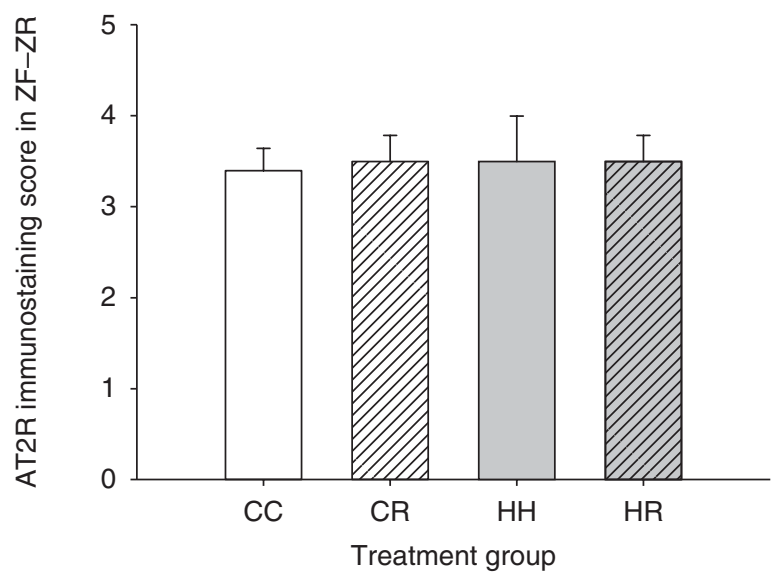

C

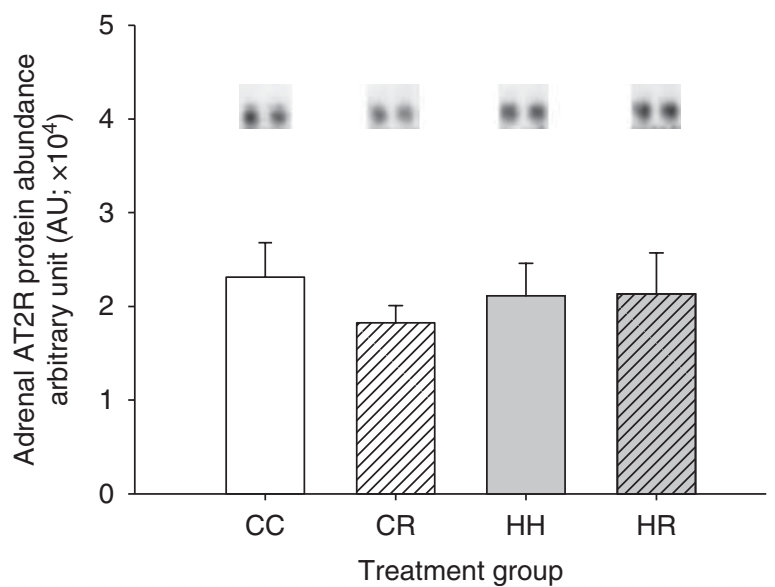

Figure 4 Intensity of AT2R immunostaining in the (A) ZG and (B) ZF-ZR of the adrenal cortex of the CC, CR, HH and HR lambs (CC, $n=5$;

$\mathrm{CR}, n=6 ; \mathrm{HH}, n=6$ and $\mathrm{HR}, n=7$ ) at 4 months of age. (C) Abundance of AT2R protein as determined by western blotting in the adrenal cortex of the CC, CR, HH and HR lambs (CC, $n=6 ; \mathrm{CR}, n=6 ; \mathrm{HH}, n=6$ and $\mathrm{HR}, n=6)$. Representative western blots from two animals in each group for AT2R are presented. has a significantly greater impact on the programming of the RAS in the post-natal adrenal.

The synthesis and secretion of aldosterone in the ZG play a key role in the regulation of systemic blood pressure. It has been shown that a low-protein diet during the periconceptional or preimplantation period results in higher systolic blood pressure in the young adult offspring in rodents (Langley-Evans et al. 1996, Kwong et al. 2000, Watkins et al. 2011). In sheep, maternal undernutrition during the periconceptional period resulted in an increase in arterial blood pressure in twin fetal sheep during late gestation, but there was no impact of an intrafetal infusion of an ACE inhibitor on arterial blood pressure in these animals (Edwards \& McMillen 2002a). Maternal dietary restriction during the first 30 days of gestation altered baroreflex function in young adult sheep and there was a blunting of the baroreflex sensitivity during Ang II infusion in these animals (Gardner et al. 2004). In sheep, $11 \beta$-hydroxylase (CYP11B) is present throughout the adrenal cortex including the ZG and ZF-ZR, which is different from its pattern of localisation in the rat, mouse, hamster, guinea pig and human adrenal (Boon et al. 1997, Okamoto et al. 2005). It has been previously shown that there was no difference in the intensity of CYP11B immunostaining between the ZG and the ZF in the fetal and adult sheep adrenal (Coulter et al. 2000). In this study, while AT1R was up-regulated in the ZG in the CR and $H R$ lambs, we found no evidence for an up-regulation of the expression of $C Y P 11 B$, which plays a key role in aldosterone synthesis (Boon et al. 1997, Okamoto et al. 2005), in the adrenal of the offspring. The lack of ability to completely separate the ZG in the lamb adrenal in this study limits the capacity to measure $C Y P 11 B$ mRNA expression in the ZG. This suggests that the activation of the intra-adrenal RAS might be more likely to play a local rather than a systemic role. In order to determine whether there is a systemic role for the RAS, measures of circulating aldosterone concentrations would be warranted.

We found that AT1R immunostaining was more intense within the ZF-ZR than in the ZG in the lamb adrenals. This is in contrast to previous studies that have shown that AT1R was predominantly present in the ZG in fetal, newborn, non-pregnant and pregnant sheep (Bird et al. 1996, Wintour et al. 1999, Coulter et al. 2000, Peterson et al. 2001). The discrepancy in AT1R localisation within the adrenal cortex may be due to the use of different antisera in different studies or a consequence of different stages of development. AT2R immunostaining was homogenous throughout the lamb adrenal, which is consistent with a recent study in the bovine adrenal (Harada et al. 2010).

In this study, we have demonstrated that dietary restriction in normal and obese ewes during the periconceptional period (CR and HR groups) resulted in an activation of the downstream components of the 
A
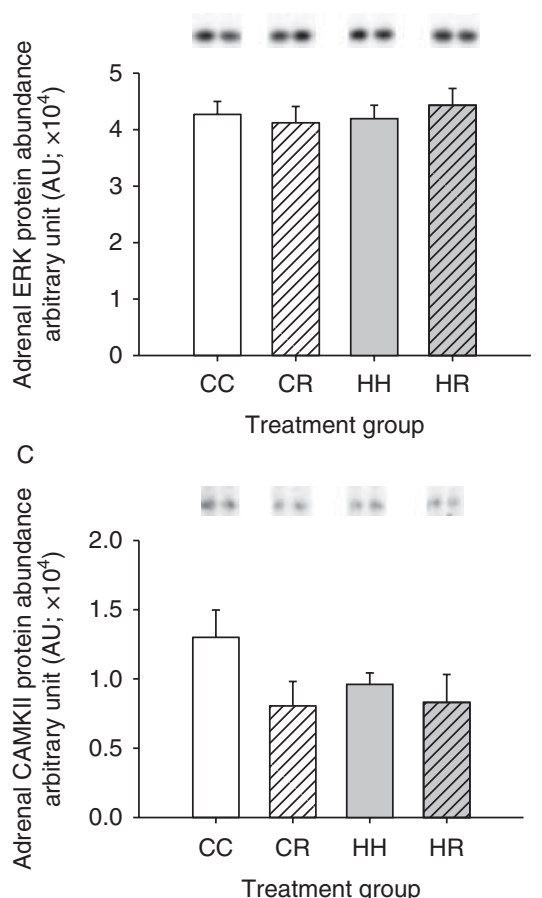

B

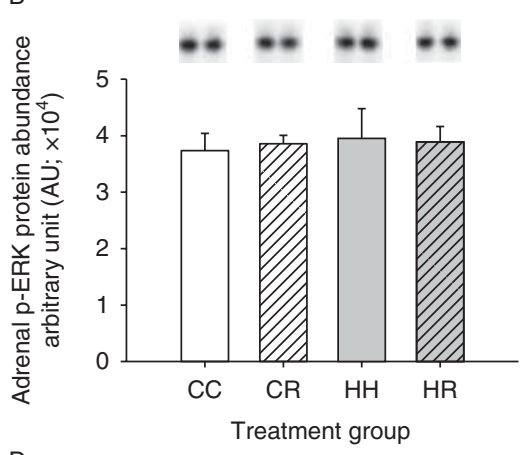

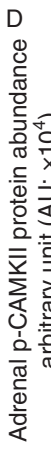

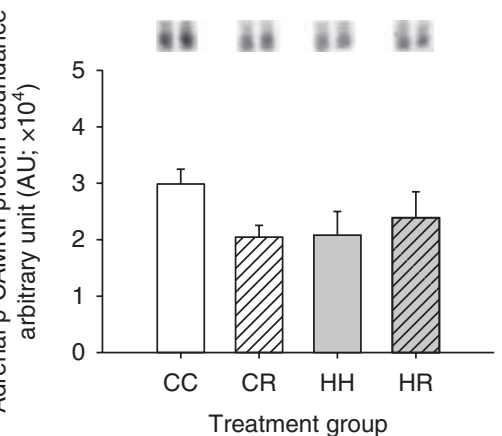

Figure 5 The protein abundance of AT1R downstream signalling molecules including (A) ERK, (B) Thr202/Tyr204 phospho-ERK (p-ERK), (C) CAMKII and (D) Thr 286 phospho-CAMKII (p-CAMKII) in the adrenal cortex of the CC, CR, HH and $\mathrm{HR}$ lambs (CC, $n=6 ; \mathrm{CR}, n=6 ; \mathrm{HH}, n=6$ and $\mathrm{HR}, n=6)$. Representative western blots from two animals in each group for ERK, p-ERK, CAMKII and p-CAMKII are presented. intra-adrenal RAS through an increase in the abundance of ACE and AT1R in the adrenal cortex of their offspring at 4 months of age. The increased abundance of ACE and AT1R was not associated with changes in ACE and AT1R methylation or mRNA expression. Further investigation on other AT1R downstream signalling molecules including JNKs or JAK/STAT should be a focus for future studies investigating the mechanisms by which AT1R may stimulate adrenal growth. These studies highlight that weight loss around the time of conception, independent of maternal body weight, results in changes within the intra-adrenal RAS, which are consistent with an increase in AT1R activation. These changes within the intraadrenal RAS system may contribute to the greater adrenal stress response following exposure to signals of adversity in the periconceptional period.

\section{Declaration of interest}

The authors declare that there is no conflict of interest that could be perceived as prejudicing the impartiality of the research reported.

\section{Funding}

This study was supported by funding from the Brailsford Robertson Trust (I C McMillen), the National Health and Medical Research Council of Australia (I C McMillen and $\mathrm{J}$ L Morrison) and the Division of Health Sciences in the University of South Australia (S Zhang, J L Morrison and I C McMillen). J L Morrison was funded by the Heart Foundation South Australian Cardiovascular Research Network.

\section{Acknowledgements}

The authors gratefully acknowledge the experiment and research assistance provided by Laura O'Carroll and the Early Origins of Adult Health Research group during the course of this study.

\section{References}

Agricultural and Food Research Council 1993 Energy and protein requirements of ruminants an advisory manual prepared by the AFRC technical committee on responses to nutrients. G Alderman, B R Cottrill Wallingford, UK: CAB International.

Aguilar F, Lo M, Claustrat B, Saez JM, Sassard J \& Li JY 2004 Hypersensitivity of the adrenal cortex to trophic and secretory effects of angiotensin II in Lyon genetically-hypertensive rats. Hypertension $\mathbf{4 3}$ 87-93. (doi:10.1161/01.HYP.0000107194.44040.d4)

Bader M \& Ganten D 2008 Update on tissue renin-angiotensin systems. Journal of Molecular Medicine 86 615-621. (doi:10.1007/s00109-0080336-0)

Bartel DP 2009 MicroRNAs: target recognition and regulatory functions. Cell 136 215-233. (doi:10.1016/j.cell.2009.01.002)

Belaud-Rotureau M-A, Parrens M, Dubus P, Garroste J-C, de Mascarel A \& Merlio J-P 2002 A comparative analysis of FISH, RT-PCR, PCR, and immunohistochemistry for the diagnosis of mantle cell lymphomas. Modern Pathology 15 517-525. (doi:10.1038/modpathol.3880556)

Bird IM, Zheng J, Corbin CJ, Magness RR \& Conley AJ 1996 Immunohistochemical analysis of AT1 receptor versus P450c17 and $3 \beta$ HSD expression in ovine adrenals. Endocrine Research 22 349-353.

Bloomfield FH, Oliver MH, Hawkins P, Campbell M, Phillips DJ, Gluckman PD, Challis JR \& Harding JE 2003 A periconceptional nutritional origin for noninfectious preterm birth. Science 300606. (doi:10.1126/science.1080803)

Bloomfield FH, Oliver MH, Hawkins P, Holloway AC, Campbell M, Gluckman PD, Harding JE \& Challis JRG 2004 Periconceptional undernutrition in sheep accelerates maturation of the fetal hypothalamic-pituitary-adrenal axis in late gestation. Endocrinology 145 4278-4285. (doi:10.1210/en.2004-0424) 
Bogdarina I, Welham S, King PJ, Burns SP \& Clark AJ 2007 Epigenetic modification of the renin-angiotensin system in the fetal programming of hypertension. Circulation Research 100 520-526. (doi:10.1161/01. RES.0000258855.60637.58)

Bogdarina I, Haase A, Langley-Evans S \& Clark AJ 2010 Glucocorticoid effects on the programming of AT1b angiotensin receptor gene methylation and expression in the rat. PLOS ONE 5 e9237. (doi:10.1371/ journal.pone.0009237)

Boon WC, Roche PJ, Butkus A, McDougall JG, Jeyaseelan K \& Coghlan JP 1997 Functional and expression analysis of ovine steroid $11 \beta$-hydroxylase (cytochrome P450 11ß). Endocrine Research 23 325-347. (doi:10.1080/ 07435809709031861)

Bushati N \& Cohen SM 2007 microRNA functions. Annual Review of Cell and Developmental Biology 23 175-205. (doi:10.1146/annurev.cellbio. 23.090506.123406)

Butler TG, Schwartz J \& McMillen IC 2002 Differential effects of the early and late intrauterine environment on corticotrophic cell development. Journal of Clinical Investigation 110 783-791. (doi:10.1172/JCI15563)

Ceolotto G, Papparella I, Bortoluzzi A, Strapazzon G, Ragazzo F, Bratti P, Fabricio AS, Squarcina E, Gion M, Palatini P et al. 2011 Interplay between miR-155, AT1R A1166C polymorphism, and AT1R expression in young untreated hypertensives. American Journal of Hypertension $\mathbf{2 4}$ 241-246. (doi:10.1038/ajh.2010.211)

Chadio SE, Kotsampasi B, Papadomichelakis G, Deligeorgis S, Kalogiannis D, Menegatos I \& Zervas G 2007 Impact of maternal undernutrition on the hypothalamic-pituitary-adrenal axis responsiveness in sheep at different ages postnatal. Journal of Endocrinology 192 495-503. (doi:10.1677/JOE-06-0172)

Clyne CD, Nicol MR, MacDonald S, Williams BC \& Walker SW 1993 Angiotensin II stimulates growth and steroidogenesis in zona fasciculata/reticularis cells from bovine adrenal cortex via the AT1 receptor subtype. Endocrinology 132 2206-2212. (doi:10.1210/en.132.5.2206)

Condon JC, Pezzi V, Drummond BM, Yin S \& Rainey WE 2002 Calmodulin-dependent kinase I regulates adrenal cell expression of aldosterone synthase. Endocrinology 143 3651-3657. (doi:10.1210/en. 2001-211359)

Côté M, Muyldermans J, Chouinard L \& Gallo-Payet N 1998 Involvement of tyrosine phosphorylation and MAPK activation in the mechanism of action of ACTH, angiotensin II and vasopressin. Endocrine Research 24 415-419. (doi:10.3109/07435809809032625)

Coulter CL, Myers DA, Nathanielsz PW \& Bird IM 2000 Ontogeny of angiotensin II type 1 receptor and cytochrome P450c11 in the sheep adrenal gland. Biology of Reproduction 62 714-719. (doi:10.1095/ biolreprod62.3.714)

Dodic M, Hantzis V, Duncan J, Rees S, Koukoulas I, Johnson K, Wintour EM \& Moritz K 2002 Programming effects of short prenatal exposure to cortisol. FASEB Journal 16 1017-1026. (doi:10.1096/fj.01-1045com)

Edwards LJ \& McMillen IC 2002a Periconceptional nutrition programs development of the cardiovascular system in the fetal sheep. American Journal of Physiology. Regulatory, Integrative and Comparative Physiology 283 R669-R679. (doi:10.1152/ajpregu.00736.2001)

Edwards LJ \& McMillen IC $2002 b$ Impact of maternal undernutrition during the periconceptional period, fetal number, and fetal sex on the development of the hypothalamo-pituitary adrenal axis in sheep during late gestation. Biology of Reproduction 66 1562-1569. (doi:10.1095/ biolreprod66.5.1562

Fern RJ, Hahm MS, Lu HK, Liu LP, Gorelick FS \& Barrett PQ 1995 $\mathrm{Ca}^{2+} /$ calmodulin-dependent protein kinase II activation and regulation of adrenal glomerulosa $\mathrm{Ca}^{2+}$ signaling. American Journal of Physiology. Renal Physiology 269 F751-F760.

Finn FM, Stehle C, Ricci P \& Hofmann K 1988 Angiotensin stimulation of adrenal fasciculata cells. Archives of Biochemistry and Biophysics 264 160-167. (doi:10.1016/0003-9861(88)90581-4)

Forhead AJ, Lamb CA, Franko KL, O'Connor DM, Wooding FB, Cripps RL, Ozanne S, Blache D, Shen QW, Du M et al. 2008 Role of leptin in the regulation of growth and carbohydrate metabolism in the ovine fetus during late gestation. Journal of Physiology 586 2393-2403. (doi:10.1113/jphysiol.2007.149237)

Gardner DS, Pearce S, Dandrea J, Walker R, Ramsay MM, Stephenson T \& Symonds ME 2004 Peri-implantation undernutrition programs blunted angiotensin II evoked baroreflex responses in young adult sheep. Hypertension 43 1290-1296. (doi:10.1161/01.HYP.0000126991. 67203.7b)

Gardner DS, Van Bon BW, Dandrea J, Goddard PJ, May SF, Wilson V, Stephenson T \& Symonds ME 2006 Effect of periconceptional undernutrition and gender on hypothalamic-pituitary-adrenal axis function in young adult sheep. Journal of Endocrinology 190 203-212. (doi:10. 1677/joe.1.06751)

Goyal R, Goyal D, Leitzke A, Gheorghe CP \& Longo LD 2010 Brain reninangiotensin system: fetal epigenetic programming by maternal protein restriction during pregnancy. Reproductive Sciences 17 227-238. (doi:10.1177/1933719109351935)

Grace CE, Kim S-J \& Rogers JM 2011 Maternal influences on epigenetic programming of the developing hypothalamic-pituitary-adrenal axis. Birth Defects Research. Part A, Clinical and Molecular Teratology 91 797-805. (doi:10.1002/bdra.20824)

Greenwood PL, Slepetis RM \& Bell AW 2000 Influences on fetal and placental weights during mid to late gestation in prolific ewes well nourished throughout pregnancy. Reproduction, Fertility, and Development 12 149-156. (doi:10.1071/RD00053)

Gross M-L, Meyer H-P, Ziebart H, Rieger P, Wenzel U, Amann K, Berger I, Adamczak M, Schirmacher P \& Ritz E 2007 Calcification of coronary intima and media: immunohistochemistry, backscatter imaging, and $X$-ray analysis in renal and nonrenal patients. Clinical Journal of the American Society of Nephrology 2 121-134. (doi:10.2215/CJN. 01760506)

Harada K, Matsuoka H, Fujimoto N, Endo Y, Hasegawa Y, Matsuo A, Kikuchi Y, Matsumoto T \& Inoue M 2010 Localization of type-2 angiotensin II receptor in adrenal gland. Journal of Histochemistry and Cytochemistry 58 585-593. (doi:10.1369/jhc.2010.955575)

Hattangady NG, Olala LO, Bollag WB \& Rainey WE 2012 Acute and chronic regulation of aldosterone production. Molecular and Cellular Endocrinology 350 151-162. (doi:10.1016/j.mce.2011.07.034)

Hoeflich A \& Bielohuby M 2009 Mechanisms of adrenal gland growth: signal integration by extracellular signal regulated kinases $1 / 2$. Journal of Molecular Endocrinology 42 191-203. (doi:10.1677/JME-08-0160)

Kakar MA, Maddocks S, Lorimer MF, Kleemann DO, Rudiger SR, Hartwich KM \& Walker SK 2005 The effect of peri-conception nutrition on embryo quality in the superovulated ewe. Theriogenology 64 1090-1103. (doi:10.1016/j.theriogenology.2004.12.017)

Kwong WY, Wild AE, Roberts P, Willis AC \& Fleming TP 2000 Maternal undernutrition during the preimplantation period of rat development causes blastocyst abnormalities and programming of postnatal hypertension. Development 127 4195-4202.

Lambert DW, Hooper NM \& Turner AJ 2008 Angiotensin-converting enzyme 2 and new insights into the renin-angiotensin system. Biochemical Pharmacology 75 781-786. (doi:10.1016/j.bcp.2007.08.012)

Langley-Evans SC, Welham SJ, Sherman RC \& Jackson AA 1996 Weanling rats exposed to maternal low-protein diets during discrete periods of gestation exhibit differing severity of hypertension. Clinical Science $\mathbf{9 1}$ 607-615.

Lebrethon MC, Jaillard C, Defayes G, Begeot M \& Saez JM 1994 Human cultured adrenal fasciculata-reticularis cells are targets for angiotensin-II: effects on cytochrome P450 cholesterol side-chain cleavage, cytochrome P450 17 $\alpha$-hydroxylase, and 3 $\beta$-hydroxysteroid-dehydrogenase messenger ribonucleic acid and proteins and on steroidogenic responsiveness to corticotropin and angiotensin-II. Journal of Clinical Endocrinology and Metabolism 78 1212-1219. (doi:10.1210/jc.78.5.1212)

Levitt NS, Lindsay RS, Holmes MC \& SeckI JR 1996 Dexamethasone in the last week of pregnancy attenuates hippocampal glucocorticoid receptor gene expression and elevates blood pressure in the adult offspring in the rat. Neuroendocrinology 64 412-418. (doi:10.1159/000127146)

MacLaughlin SM, Walker SK, Kleemann DO, Sibbons JP, Tosh DN, Gentili S, Coulter CL \& McMillen IC 2007 Impact of periconceptional undernutrition on adrenal growth and adrenal insulin-like growth factor and steroidogenic enzyme expression in the sheep fetus during early pregnancy. Endocrinology 148 1911-1920. (doi:10.1210/en. 2006-0761)

Marrero MB, Schieffer B, Paxton WG, Heerdt L, Berk BC, Delafontaine P \& Bernstein KE 1995 Direct stimulation of Jak/STAT pathway by the angiotensin II AT1 receptor. Nature 375 247-250. (doi:10.1038/ 375247a0) 
McEwan PE, Vinson GP \& Kenyon CJ 1999 Control of adrenal cell proliferation by AT1 receptors in response to angiotensin II and lowsodium diet. American Journal of Physiology. Endocrinology and Metabolism 276 E303-E309.

Muller PY, Janovjak H, Miserez AR \& Dobbie Z 2002 Processing of gene expression data generated by quantitative real-time RT-PCR. BioTechniques 32 1372-1379.

Murgatroyd C, Patchev AV, Wu Y, Micale V, Bockmuhl Y, Fischer D, Holsboer F, Wotjak CT, Almeida OFX \& Spengler D 2009 Dynamic DNA methylation programs persistent adverse effects of early-life stress. Nature Neuroscience 12 1559-1566. (doi:10.1038/nn.2436)

Nussdorfer GG, Robba C, Mazzochi G \& Rebuffat P 1981 Effects of angiotensin II on the zona fasciculata of the rat adrenal cortex: an ultrastructural stereologic study. Journal of Anatomy 132 235-242.

Oberlander TF, Weinberg J, Papsdorf M, Grunau R, Misri S \& Devlin AM 2008 Prenatal exposure to maternal depression, neonatal methylation of human glucocorticoid receptor gene (NR3C1) and infant cortisol stress responses. Epigenetics 3 97-106. (doi:10.4161/epi.3.2.6034)

Okamoto M, Nonaka Y, Takemori H \& Doi J 2005 Molecular identity and gene expression of aldosterone synthase cytochrome P450. Biochemical and Biophysical Research Communications 338 325-330. (doi:10.1016/ j.bbrc.2005.07.187)

Otis M, Campbell S, Payet MD \& Gallo-Payet N 2005 Angiotensin II stimulates protein synthesis and inhibits proliferation in primary cultures of rat adrenal glomerulosa cells. Endocrinology 146 633-642. (doi:10.1210/en.2004-0935)

Passmore M, Nataatmadja M \& Fraser JF 2009 Selection of reference genes for normalisation of real-time RT-PCR in brain-stem death injury in Ovis aries. BMC Molecular Biology 10 72. (doi:10.1186/1471-2199-10-72)

Peters J 2012 Local renin-angiotensin systems in the adrenal gland. Peptides 34 427-432. (doi:10.1016/j.peptides.2012.01.023)

Peterson JK, Moran F, Conley AJ \& Bird IM 2001 Zonal expression of endothelial nitric oxide synthase in sheep and rhesus adrenal cortex. Endocrinology 142 5351-5363. (doi:10.1210/en.142.12.5351)

Phillips DI, Walker BR, Reynolds RM, Flanagan DE, Wood PJ, Osmond C, Barker DJ \& Whorwood CB 2000 Low birth weight predicts elevated plasma cortisol concentrations in adults from 3 populations. Hypertension 35 1301-1306. (doi:10.1161/01.HYP.35.6.1301)

Rattanatray L, MacLaughlin SM, Kleemann DO, Walker SK, Muhlhausler BS \& McMillen IC 2010 Impact of maternal periconceptional overnutrition on fat mass and expression of adipogenic and lipogenic genes in visceral and subcutaneous fat depots in the postnatal lamb. Endocrinology 151 5195-5205. (doi:10.1210/en.2010-0501)

Rivière G, Michaud A, Breton C, VanCamp G, Laborie C, Enache M, Lesage J, Deloof S, Corvol P \& Vieau D 2005 Angiotensin-converting enzyme 2 (ACE2) and ACE activities display tissue-specific sensitivity to undernutrition-programmed hypertension in the adult rat. Hypertension 46 1169-1174. (doi:10.1161/01.HYP.0000185148.27901.fe)

Roks AJM, van Geel PP, Pinto YM, Buikema H, Henning RH, de Zeeuw D \& van Gilst WH 1999 Angiotensin-(1-7) is a modulator of the human renin-angiotensin system. Hypertension 34 296-301. (doi:10.1161/01. HYP.34.2.296)

Romero DG, Welsh BL, Gomez-Sanchez EP, Yanes LL, Rilli S \& GomezSanchez CE 2006 Angiotensin II-mediated protein kinase D activation stimulates aldosterone and cortisol secretion in H295R human adrenocortical cells. Endocrinology 147 6046-6055. (doi:10.1210/en.2006-0794)

Ross JT, McMillen IC, Lok F, Thiel AG, Owens JA \& Coulter CL 2007 Intrafetal insulin-like growth factor-I infusion stimulates adrenal growth but not steroidogenesis in the sheep fetus during late gestation. Endocrinology 148 5424-5432. (doi:10.1210/en.2006-1573)
Russel AJF, Doney JM \& Gunn RG 1969 Subjective assessment of body fat in live sheep. Journal of Agricultural Science 97 723-729.

Stevens A, Begum G, Cook A, Connor K, Rumball C, Oliver M, Challis J, Bloomfield F \& White A 2010 Epigenetic changes in the hypothalamic proopiomelanocortin and glucocorticoid receptor genes in the ovine fetus after periconceptional undernutrition. Endocrinology 151 3652-3664. (doi:10.1210/en.2010-0094)

Szekeres M, Turu G, Orient A, Szalai B, Süpeki K, Cserzo M, Várnai P \& Hunyady L 2009 Mechanisms of angiotensin II-mediated regulation of aldosterone synthase expression in $\mathrm{H} 295 \mathrm{R}$ human adrenocortical and rat adrenal glomerulosa cells. Molecular and Cellular Endocrinology 302 244-253. (doi:10.1016/j.mce.2008.12.015)

Viard I, Rainey WE, Capponi AM, Begeot M \& Saez JM 1990 Ovine adrenal fasciculata cells contain angiotensin-II receptors coupled to intracellular effectors but are resistant to the steroidogenic effects of this hormone. Endocrinology 127 2071-2078. (doi:10.1210/endo-1275-2071)

de Vries A, Holmes MC, Heijnis A, Seier JV, Heerden J, Louw J, WolfeCoote S, Meaney MJ, Levitt NS \& Seckl JR 2007 Prenatal dexamethasone exposure induces changes in nonhuman primate offspring cardiometabolic and hypothalamic-pituitary-adrenal axis function. Journal of Clinical Investigation 117 1058-1067. (doi:10.1172/JCl30982)

Watkins AJ, Lucas ES, Wilkins A, Cagampang FR \& Fleming TP 2011 Maternal periconceptional and gestational low protein diet affects mouse offspring growth, cardiovascular and adipose phenotype at 1 year of age. PLOS ONE 6 e28745. (doi:10.1371/journal.pone.0028745)

Weaver ICG, Cervoni N, Champagne FA, D'Alessio AC, Sharma S, Seckl JR, Dymov S, Szyf M \& Meaney MJ 2004 Epigenetic programming by maternal behavior. Nature Neuroscience 7 847-854. (doi:10.1038/ nn1276)

Whorwood CB, Firth KM, Budge H \& Symonds ME 2001 Maternal undernutrition during early to midgestation programs tissue-specific alterations in the expression of the glucocorticoid receptor, $11 \beta$-hydroxysteroid dehydrogenase isoforms, and type 1 angiotensin II receptor in neonatal sheep. Endocrinology 142 2854-2864. (doi:10.1210/en.142.7.2854)

Wintour EM, Moritz K, Butkus A, Baird R, Albiston A \& Tenis N 1999 Ontogeny and regulation of the AT1 and AT2 receptors in the ovine fetal adrenal gland. Molecular and Cellular Endocrinology 157 161-170. (doi:10.1016/S0303-7207(99)00149-5)

Xiong Z \& Laird PW 1997 COBRA: a sensitive and quantitative DNA methylation assay. Nucleic Acids Research 25 2532-2534. (doi:10.1093/ nar/25.12.2532)

Zhang A, Ding G, Huang S, Wu Y, Pan X, Guan X, Chen R \& Yang T 2005 c-Jun $\mathrm{NH} 2$-terminal kinase mediation of angiotensin II-induced proliferation of human mesangial cells. American Journal of Physiology. Renal Physiology 288 F1118-F1124. (doi:10.1152/ajprenal.00220.2004)

Zhang S, Rattanatray L, MacLaughlin SM, Cropley JE, Suter CM, Molloy L, Kleemann D, Walker SK, Muhlhausler BS, Morrison JL et al. 2010 Periconceptional undernutrition in normal and overweight ewes leads to increased adrenal growth and epigenetic changes in adrenal IGF2/H19 gene in offspring. FASEB Journal 24 2772-2782. (doi:10.1096/fj.09-154294)

Received 20 May 2013

First decision 14 June 2013

Revised manuscript received 14 August 2013

Accepted 15 August 2013 